\title{
The political affordances of the 'coconut wireless' Rotumans on social media in the 2018 Fiji elections
}

\begin{abstract}
As a unique group of people, Rotumans make up less than two percent of Fiji's population, and as a minority Indigenous ethnic group in Fiji, they have remained relatively hidden and silent in political affairs. Outmigration from the island has led to more than 80 percent of Rotumans residing outside of Rotuma. In recent times, the Rotuman diaspora has heavily relied on the use of ICTs and new media technologies as crucial tools for the reinvigoration of Rotuma's culture. This in itself poses an intriguing paradox as internet connectivity on Rotuma is quite limited. However, social media platforms have been increasingly used by Rotumans outside of Rotuma, and have enabled increased connectivity and greater dissemination of information among the Rotuman diaspora. Recently, the primary purpose of such social media groups has evolved from merely being a tool for rekindling familial ties, to being a platform for political discourse on Rotuman issues. In essence, despite the scattered nature of the Rotuman population, digital technologies are offering Rotumans the affordance of being able to inform and educate themselves and their networks on political issues of Rotuman interest. By employing ethnography and netnography principles and through in-person and online engagement with Rotumans within and outside of Rotuma, this article examines the affordances that digital technologies offer Rotumans concerning national political discourse. This is carried out with a specific focus on the 2018 general elections in Fiji.
\end{abstract}

Keywords: Fiji, digital affordances, digital diaspora, digital divide, elections, ethnography, freedom of expression, Indigenous, Rotuma, social media

RUFINO VAREA

JASON TITIFANUE

RENATA VAREA

ROMITESH KANT

The University of the South Pacific, Fiji 


\section{Introduction}

OTUMA is an island that is part of the Republic of Fiji, and Rotumans are a minority Indigenous ethnic group with a unique culture and history. As a minority Indigenous people, Rotuman issues and concerns have typically been subsumed within the greater realm of national-level political issues and turbulences in Fiji. Such political turbulence has only served to exacerbate existing societal divisions. Particularly as after the 2006 coup, there followed eight years of authoritarian rule before another general election took place in Fiji (Kant, 2017). This turbulence has had an impact on the political representation and participation of Rotumans.

For ethnic minorities around the world, internet platforms offer a means for the (re)production of identity from a community level (Khalidi, 1997; Mpofu, 2013). Despite the digital divide, the global disparity in access to digital media between 'haves' and 'have-nots, this means that the internet and social media offer possibilities of greater connectivity amongst Rotumans, thus amplifying their voices into the political sphere. Freedom of expression is a fundamental human right, as well as a vital component of democracy. The ability of citizens to freely express themselves is also intricately linked to the notion of development. The idea that media represents a space where cultural communities (especially Indigenous peoples) can engage in identity contestation and, as a result, identity and culture-based mobilisation and political action is not new. Sreberny-Mohammadi and Mohammadi (1994) linked culture, identity, and communication to protest and resistance. They argued that community-led media could provide spaces to articulate and disseminate alternative identities from those presented in mainstream media. For ethnic minorities (such as Rotumans), their ability to raise issues of concern can be drowned out (intentionally or unintentionally) by more dominant groups. This is an issue of particular concern in the context of elections, where ethnic minorities can run the risk of having their specific issues subsumed into the larger polity. Moser (2008, p. 1) argues that achieving broad representation of ethnic groups has key ramifications for the quality of democracy in countries, particularly those that are emerging from long periods of authoritarian rule.

The advent of information and communication technologies (ICTs), and the subsequent development of social media platforms, has offered great potential for the enhancement of freedom of expression (Mpofu, 2013). Functionally, social media platforms are designed to enable ease of communication between individuals and groups. Thus, social media plays a pivotal role in political and civic engagement due to its structural and functional properties as they act to create a more inclusive and accessible political process by engaging both conventional political actors and less prominent actors to create, maintain, or expand networks (Valenzuela, Arriagada, \& Scherman, 2014). 
Constant global trends of decreasing costs of technology have meant that even in areas without internet coverage, smartphones have become ubiquitous in Rotuman households. Typical trends include families sharing the smartphones they possess so that individual family members can, for example, take turns to " $n a$ malu se Facebook ta' (put photos on Facebook). In common parlance, the word Facebook is now synonymous with contacting family members, with phrases such as 'nam fone ta la gou la po la Facebook ma...' ('give me the phone so that I can Facebook with [family member]') being commonly heard. As a result, Facebook has become a viable platform for Rotumans to maintain and rekindle connections with kin. Titifanue, Varea, Varea, Kant, and Finau (2018, p. 40) found that social media offers Rotumans the ability to reconnect and maintain familial ties that could not be easily done in the past.

In the context of communications research, Evans, Pearce, Vitak, and Treem (2016, p. 36) define affordances as 'the multifaceted relational structure between an object/technology and the user that enables or constrains potential behavioural outcomes in a particular context'. Evans et al. (2016. p. 39-40) also developed a framework to map out the role of affordances in communications research. For a phenomenon to qualify as an affordance, it must first not be an object or feature of an object; a specific feature of an object is not necessarily an affordance, rather it is what the feature allows users to do. For example, a smartphone camera is a feature while its affordance is allowing users to capture images and videos. Secondly, affordance must not be an outcome; for instance, posting a social media story of a protest is not an affordance, rather the affordance is the increased visibility that social media offers. Lastly, affordance should have variability; individuals use features differently and for differing outcomes. Thus, a social media site can be used for activism, or it can be used solely for social purposes.

'Coconut wireless' is a Pacific euphemism for news that is disseminated through informal channels, such as an informal conversation between two people. It particularly refers to rumour-like information and witticism to describe how the news may seem to spread at a rate that equals or exceeds modern communication mediums. In the Rotuman context, Inia (1998, p. 233) describes the coconut wireless as a means to spread news fast (p. 13). She further goes on to describe the coconut wireless as 'infamous, and a potential producer of malicious gossip' (p. 233). In essence, how information may be conveyed, and transformed between people through conversations or online multimedia platforms could influence the information itself.

To contextualise this concept, only half of Rotuma receives mobile network connectivity, though depending on the proximity of an area to the telecommunications tower, individuals may have access to both internet, calling and texting services, or solely to calling and messaging. However, in a particular district that lies outside of the zone of mobile network coverage, there is a single coconut tree where the mobile 
network signal can be received. So, a person who resides in this area of Rotuma, and has a mobile phone, may be in touch with information on the internet or through phone calls. When such information is then passed on through conversations with others residing in the same area, this information may change or a new version of the information may form through the 'coconut wireless'. Herein, the term 'digital coconut wireles' is referred to as online information, concerning Fiji and Rotuman affairs, that is spread at an inexorable pace through social media platform such as forums or groups, whether verified or not.

To understand and unpack the influence of the digital coconut wireless, this article analyses the use of social media as a political tool for the indigenous group of Rotumans. The article further examines the affordances that digital technologies offer in relation to (re)invigorating cultural identity, and contributing to national political discourse, with a specific focus on the 2018 general elections in Fiji. The article seeks to demonstrate the applicability of the affordances theory, and showcase how it is demonstrated in the political use of social media by Rotumans. The article seeks to determine how increased access to digital technologies has enabled the creation of a Rotuman public sphere that transcends the online and offline realms.

\section{Methods}

The ethnographic (Genzuk, 2003) and netnographic (Kozinets, 2010) research methods were deployed with a combination of closed and open questions in a questionnaire co-designed by researchers. Interviews were conducted in 2018 with Rotumans who resided on mainland Fiji (Viti Levu) and those residing on the island of Rotuma, through focus groups and speaking with individuals. A total of 40 Rotumans were interviewed across two geographical areas (20 participants from Rotuma Island and 20 participants from the Western Division of Viti Levu). Participants were also drawn from a wide age group ranging from 19 to 75 years old. Oral and written consent for each interview was recorded and each interview lasted an average of 45 minutes to an hour long.

\section{Rotuman political status: Political representation and constitutional status}

Rotuma (Figure 1) was ceded to the United Kingdom in 1881 and, for administrative purposes, was politically merged with the Fiji colony (Clark, 2005). An ethnically distinct group from the mainland indigenous Fijians, Rotumans' ethnic classification is a contentious issue but are generally categorised as Polynesians due to marked similarities in language, culture and physical appearance (Biggs, 1965).

As of the 2017 Fiji Census, the island of Rotuma has a population of 1,594 (Fiji Bureau of Statistics, 2018). Most Rotumans live outside of the island (Figure 2), with 8333 Rotumans living on the mainland Fiji Islands as of the Fiji 2007 


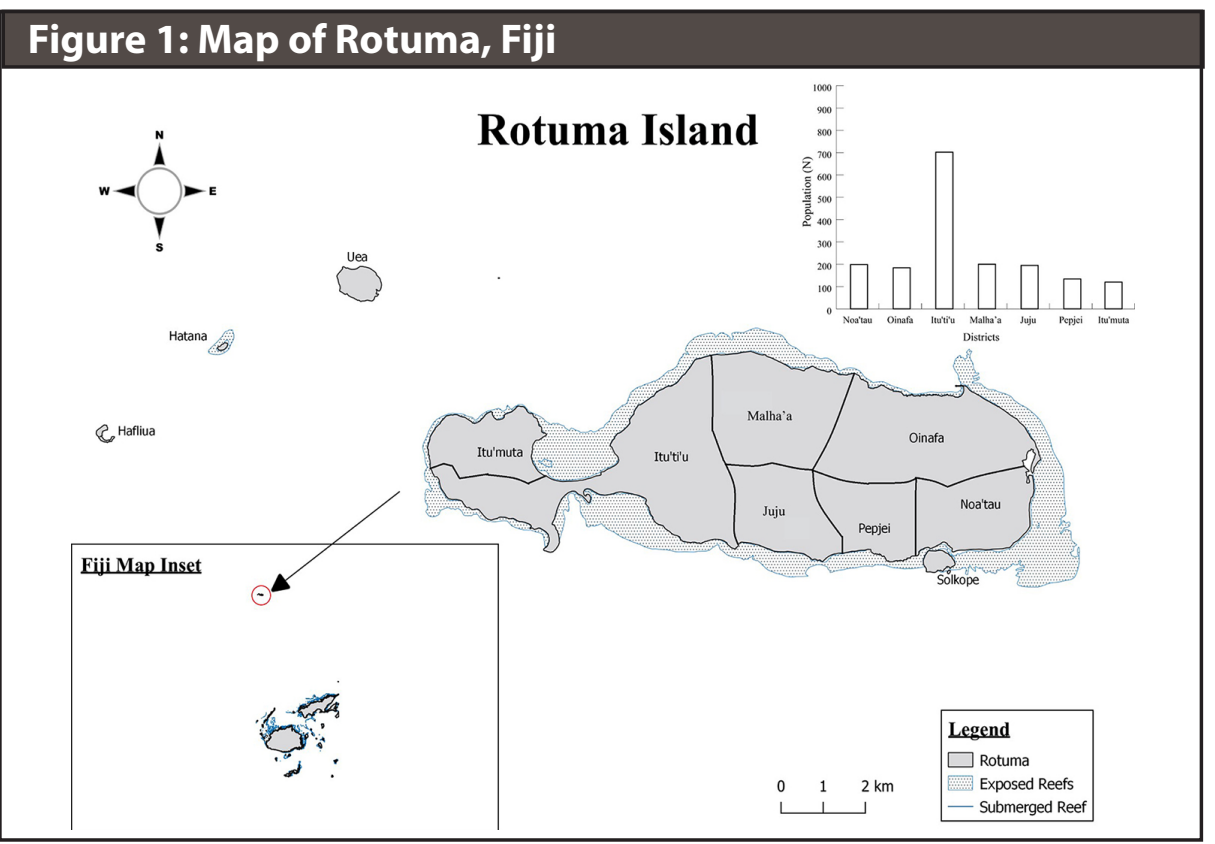

Note: Map of Rotuma, Fiji (including population by districts based on records provided by the Rotuma Hospital in 2014 and which was categorised via subdivision demographic census). The map was produced with QGIS (QGIS Development Team, 2019) by Rufino Varea; maritime boundaries from Flanders Marine Institute (2018).

Census (Fiji Bureau of Statistics, 2007) ${ }^{1}$.

Achieving a broad representation of different ethnic groups has important implications for the stability and quality of democracy, particularly in polities just emerging out of long periods of authoritarian rule. (Moser, 2008, p. 273)

As a minority Indigenous group, the ability of Rotumans to garner representation at the national level has been highly dependent upon the provisions made by Fiji's Constitutions. Since Fiji's independence in 1970, Fiji has had four constitutions. Each of these constitutions has made a profound impact on the ability of Rotumans to have a representative at the parliamentary level.

Since the process of decolonisation began in Fiji in the 1960s, debates around constitutional design have witnessed contentious debates around having an integrated, non-racial state, based on individual rights and those who favour a political order based on ethnic communities; civic and ethnic nationalisms (Kant, 2017). Rotumans chose to remain as part of Fiji.

Rotumans are recognised simultaneously as Indigenous, though different from Indigenous Fijians and their 'uniqueness' has been emphasised at multiple legal and policy echelons (Irava, 1991). Such recognition is exemplified by preamble provisions in the four constitutions of Fiji indicating the importance of 


\section{Figure 2: Total population of Rotumans, 2020}

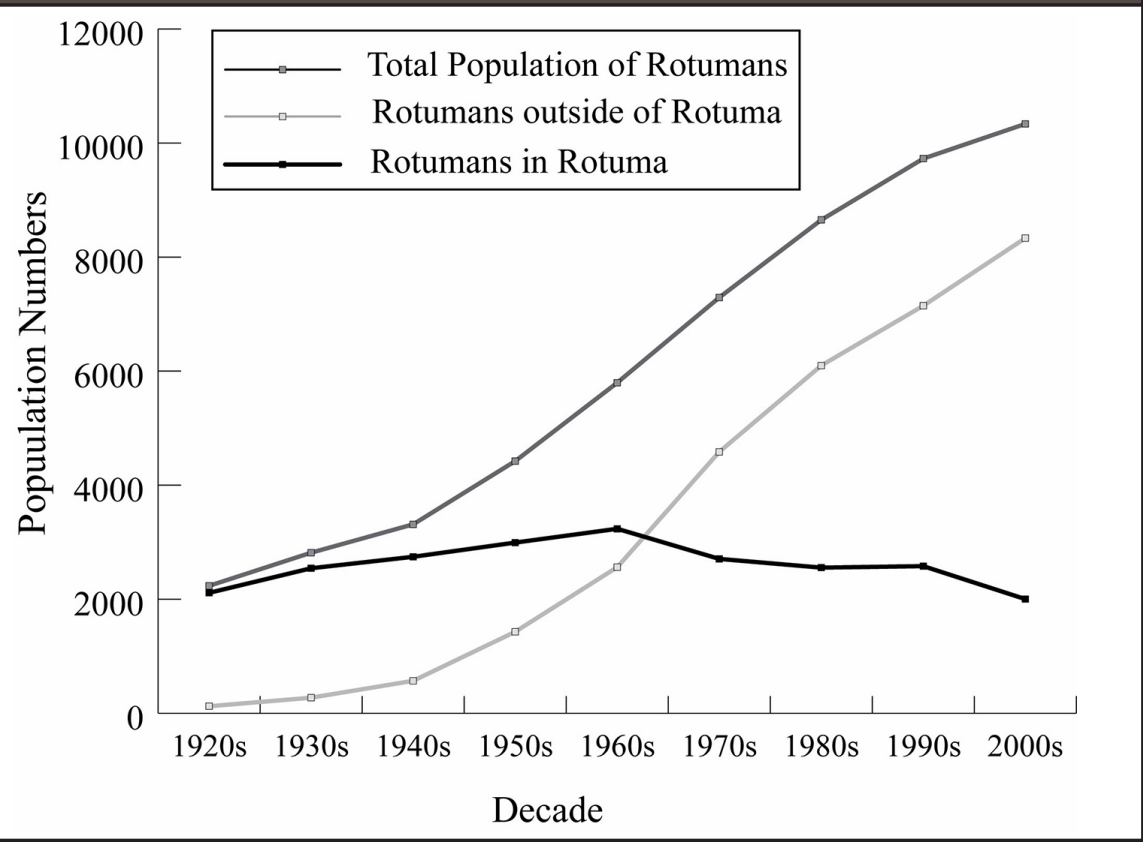

Note: Total population of Rotumans, including the number of Rotumans who live in and outside of Rotuma.

Rotuma as part of the broader political landscape in Fiji. Despite this, Rotuman involvement in national decision-making (especially policy decisions affecting Rotuma) has been severely restricted by their geographic isolation, and lack of substantive provisions that afford them a seat at the decision-making table. For the Rotuman community, questions relating to the representation of the community in the Fijian parliament is linked to broader questions about the status of Rotuman people within the Fijian nation-state (Anderson, 2007, p. 186).

\section{The 1970 Constitution}

After an intense series of closed-door negotiations in 1969 and 1970 between the leaders of the two major ethnic groups (the Indigenous Fijians and IndoFijians), the 1970 Independence Constitution, was a compromise, whereby the indigenous Fijians and Indo-Fijians were allocated the same number of parliamentary seats for an in-depth analysis of the provisions of the 1970 Constitution, see Ghai and Cottrell (2008). To appease Indigenous Fijian concerns, who feared political domination by Indo-Fijians and loss of land and political rights, there was agreement that the Senate would provide greater Indigenous Fijian representation with veto powers over legislation affecting indigenous Fijian interests (Vasil, 1972, p. 28).

During these independence negotiations, Rotuman chiefs expressed the view that Rotuma should not be treated as a colony of Fiji but should be a federal 
part of the new nation consisting of Fiji and Rotuma (Howard \& Rensel, 2007, p. 343). They specifically requested a provision in the Constitution for a seat in the House of Representatives allocated to an elected representative of Rotuma arguing that Rotumans were not an immigrant race and thus deserving of special consideration (Howard \& Rensel, 2007, p. 339).

For election to the House of Representatives, Rotumans were grouped in a communal roll with Indigenous Fijians. ${ }^{2}$ However, Rotuma was given one Senate seat (out of twenty-two); to be nominated by the Council of Rotuma. ${ }^{3}$. The colonial ordinances governing Rotuma, namely the Rotuma Ordinance and Rotuma Land Ordinance became entrenched provisions of the 1970 Fiji independence Constitution, requiring extraordinary processes for amending these ordinances (Acts). ${ }^{4}$

\section{The 1990 Constitution}

In May 1987, a military coup took place in Fiji, resulting in the abrogation of the 1970 constitution. A new 1990 Constitution was promulgated to ensure indigenous Fijian political dominance (Kant, 2018, p. 65). Rotumans were removed from the indigenous Fijian communal roll and placed on a separate roll with an allocation of a single Rotuman communal seat in the House of Representatives. The provision for a senator nominated by the Rotuma Council was retained. Also retained were the constitutional entrenchment of the Rotuma Acts.

\section{The 1997 Constitution}

By the mid-1990s, there were moves to review the 1990 constitution for a more multicultural constitution that would be acceptable in Fiji and internationally. During this time, a constitutional commission was created, and a group of Rotumans made a submission on behalf of the Rotuma Council. They requested that Rotumans be awarded two representatives in the lower house, two representatives in the Senate, and the creation of a Ministry for Rotuman Affairs (Howard $\&$ Rensel, 2007, p. 359). However, the resulting 1997 Constitution retained the provision of one Rotuman communal seat in the House of Representatives, one Rotuma Senator and the constitutional entrenchment of the Rotuman Acts.

\section{The 2013 Constitution}

The 2006 coup attempted to transform the country in the opposite direction to the earlier ethno-nationalist inspired coups. The post-coup regime promised a new Constitution with an objective of 'civic nation-building' to nurture a sense of common citizenship, going beyond narrow ethnic allegiances (Kant, 2017). The post-coup regime advocated for the elimination of voting in terms of 'racial classifications', and its replacement with a system whereby 'each voter should vote for a candidate of his/her choice in a common roll, with each vote having equal value' (Kant \& Rakuita, 2014).

Fiji's 2013 Constitution makes preamble references to the Indigenous Fijians 
and Rotumans as the first inhabitants of Fiji, recognising their lands, unique culture, customs traditions and language (Fiji 2013 Constitution). A 50 multi-member single national constituency was established, meaning that parties and candidates must compete to garner votes all around the country as opposed to their individual constituencies. In addition, political parties and independent candidates must attain a 5 percent threshold of total votes cast to qualify for Parliament.

The recognition of Indigenous Fijian and Rotuman customary land ownership in the Constitution was intended to appease suspicions stirred up by ethnonationalists over most of Fiji's independent history. It is strengthened by Article 28, which confirms that Indigenous Fijian, Rotuman and Banaban land rights are inalienable. However, the provisions for previous constitutionally entrenched specific legislative provisions in the 1970, 1990 and 1997 Constitutions were done away with.

Legislative representation carries powerful symbolic power for ethnic minorities and often becomes an end in itself even when minorities have little or no chance of participating in the governing coalition. (Moser, 2008, p. 273)

The electoral provisions of the 2013 constitution also have potential ramifications for minority groups. In the Rotuman context, for instance, section 53(1) of Fiji's 2013 Constitution states: 'The election of members of Parliament is by a multi-member open list system of proportional representation, under which each voter has one vote, with each vote being of equal value, in a single national electoral roll comprising all the registered voters.' In the 2018 elections, a total of 458,532 votes were cast (FijiVillage, 2018). This means that to qualify for Parliament, political parties and independent candidates would need to attain approximately 22,926 of total votes to meet the 5 percent threshold to qualify for Parliament. This does not augur well for minority communities such as the Rotuman population as (theoretically) it could mean that if in future, all Rotumans chose to vote for an independent candidate or Rotuman political party, the number of votes cast by Rotumans would still not garner the number of votes required for the candidate/party to qualify for Parliament. In such a political environment, the validity of the mantra of 'one person, one vote, one value' can be questioned when applied to the context of minority populations in Fiji.

Common political discourse tends to overlook the fact that Rotumans are a unique Indigenous ethnic group with a culture, language, and land tenure system that is vastly different from Indigenous Fijians. Consequently, political deliberations on issues such as Indigenous rights tend to subsume Rotuman concerns into the broader spectrum of Indigenous Fijian affairs. In this political context, Rotumans, as a minority Indigenous ethnic group in Fiji, have remained relatively hidden and silent during the political turmoil. As noted by Howard (1970), Rotumans have always adopted a 'don't rock the boat' approach.

228 PACIFIC JOURNALISM REVIEW 26 (2) 2020 


\section{Elections and political representation of Rotumans}

Even though a number of notable Rotumans have been high achievers academically and professionally, the broader Rotuman community is sometimes overlooked in political decision-making. According to Anderson (2007, pp. 186187), this political marginalisation can be seen in some key government policy documents (such as the previous affirmative action program for advancement in the economic status of Indigenous Fijians from 2000-2006); in generalisations about the economic and other status of the community (ensuring that social and economic reality for many members is not addressed); in the dismissal of the legitimate political concerns voiced by some members of the community; and in the way in which the island is treated as akin to other outer islands despite its 'special status' (the difficulty in delivering goods and services, the lack of development, the expense and difficulty in travel all indicative of the latter). It is these issues of the status of Rotuma within Fiji and effective representation (for the community as a whole and as individuals), which are arguably at the crux of many Rotuman political arguments. These issues are usually invisible in the traditional media in Fiji.

Provision of special representation with a Rotuman communal seat in the 1990 and 1997 Constitutions had the effect of highlighting, albeit not prominently, Rotuman political, cultural and socio-economic issues as candidates for elections tailored manifestos for the Rotuma Communal constituency and in candidates' election campaigning (Anderson, 2007, p. 191).

With the 2013 Constitution removing communal representation, Rotuman voters have effectively been marginalised. In 2018 only two political party manifestos mentioned Rotuma. In 2014, two candidates of Rotuman ethnicity ran for the 2014 elections. These were Jioje Konousi Konrote (the current President of Fiji) and Rosarine Pasepa Lagi, who respectively ran for the FijiFirst Party (hereafter 'FijiFirst') and Fiji Labour Party (FLP). Rotuma Island, whose issues had for so long been subsumed in the broader national level discourse, had multiple developmental projects allocated-reported as being widely welcomed. In an interview with FBC News, Major-General Jioje Konrote, the then advisor to the Rotuma Island Council, stated: 'Never in the history of our little island so much has been done by any government' (Coka, 2014b). In 2014 alone, announcements were made regarding the following activities;

1. A renewable energy project which encompassed the islands of Kadavu, Rotuma and Lakeba (Fiji Village, 2014)

2. The upcoming completion of the dredging of the Oinafa jetty to improve shipping services (The Fiji Times, 2014)

3. Allocation of excavators to improve and upgrade roads on Rotuma (Nasiko, 2015; The Fijian Government, 2014b)

4. The waiving of half a million dollars in unpaid water bills on the island 
of Rotuma (Coka, 2014c)

5. The upcoming commencement of the construction of a new hospital (The Fijian Government, 2014a)

6. Government looking at the allocation of FJD $\$ 15$ million for an upgrade of the Rotuma airport (Coka, 2014a)

7. Dialogue between Fiji and Tuvalu government officials to facilitate trade between Rotuma and Tuvalu (Coka, 2014d; Fiji Sun, 2014)

During the 2014 elections, members of the ruling government ran under the FijiFirst banner and garnered the majority of votes on the island. The party gained 84.1 percent of votes, the majority for Jioje Konusi Konrote (537 votes), and the party leader Josaia Voreqe Bainimarama (177 votes). Rosarine Lagi of the FLP only garnered a total of 47 votes. FijiFirst demonstrated very high popularity on Rotuma, but upcoming events in 2015 were to change this.

In 2015, the Fiji Parliament tabled two bills relating to Rotuma and these were respectively the 'Rotuma Bill of 2015' [Bill no. 6 of 2015] and the 'Rotuma Lands Bill 2015' [Bill no. 7 of 2015]. The bills were met with concern by the Rotuman community and led Rotumans to become more politically vocal (Titifanue et al., 2018).

Rotuman concerns surrounding the bills were centred on various provisions of the bills that differed from the current Rotuma Acts. A prominent Rotuman medical practitioner stated in an interview that opposition to the Bills was not to detract from national unity but that it was a matter of 'identity' (Chand, 2017). One of the critical points of contention was the proposed change to the legal definition of Rotuma. In the current Rotuma Act [Cap 122] (Government of Fiji, 1927 — amended in 1958), Rotuma is defined as;

... the island of Rotuma and its dependencies, that is to say, all islands, rocks, reefs and fisheries lying between the twelfth degree and the fifteenth degree of south latitude and between the one hundred and seventy-fifth degree and the one hundred and eightieth degree of east longitude from the meridian of Greenwich.

In contrast, the current proposed 'Rotuma Bill' redefines Rotuma by simply referring to the 'islands of Rotuma'. The area of Rotuma is significantly reduced with its altered definition under the Rotuma Bill. Apart from this provision, there are other changes in the proposed bills that have the potential to profoundly affect Rotuma land tenure, and administration (The Fiji Times, 2017; Titifanue et al., 2018). Due to the controversy surrounding the bills, many Rotumans opposed them, with 85 percent of all voters on Rotuma Island signing a petition calling for the withdrawal of the Bills (The Fiji Times, 2017). As a result, during the 2018 elections, the proposed bills were an ever-looming presence. The 2013 
constitution removed provisions that entrenched the Rotuma Acts within the constitution. Consequently, the bills could be passed through a simple majority vote in Parliament (Sackett, Kant, \& Titifanue, 2018).

For Rotumans, the bills became a point of contention before the 2018 elections, but specific issues became glossed over, with the majority of political parties not focusing on Rotuma. Only FijiFirst and the National Federation Party (NFP) each mentioned a single matter/issue they would seek to address in their manifestos pertaining to Rotumans.

In the case of the FijiFirst Party (2018), their manifesto stated that they upheld 'the special place of our iTaukei and Rotuman people, their ownership of their lands and their unique culture, traditions, language and customs' (p. 51). The manifesto further stated that the party would work to 'further increase digital TV terrestrial coverage in Rotuma, Kadavu, Ovalau, Koro and Vanuabalavu' (p. 58). The NFP, on the other hand, made a specific focus upon the Rotuma Bills and stated that the party would work to 'repeal the Rotuma Land Bill' (National Federation Party, 2018, p. 11) Notably, while the NFP manifesto stated that the party would work to repeal one of the Rotuman Bills (the Rotuma Land Bill), no mention is made of the Rotuma Bill.

Rosarine Lagi, a Rotuman lawyer, took a centre stage role in Rotuman opposition to the bills, informing the public of updates about them. ${ }^{5}$ She employed social media to post regular updates on the status of the bills and their ramifications, which helped her garner support. In 2018, she again stood for election as an NFP candidate. During a campaign meeting, she spoke about her work in coordinating opposition to the Rotuma bills.

In between the 2014 and 2018 elections, Rotuma continued to receive developmental assistance and projects. The major promises made by FijiFirst before the 2014 elections to the Rotuman people were kept. Work commenced on the airport upgrade and hospital construction that had been announced in the build-up to the 2014 elections. On October 29, the airport which had undergone a runway upgrade worth F\$12.8 million was opened by the Prime Minister of Fiji (Fiji Sun, 2018). At the same time, work continued on the construction of a new hospital for Rotuma (the total cost of the construction is estimated to be F\$8.3 million) (Bolatiki, 2018). However, the election results revealed erosion in the popularity of the FijiFirst Party.

Much of Fiji followed a trend of the vote being split between the FijiFirst and SODELPA parties. Voting trends on Rotuma differed, with the majority of votes being divided between the FijiFirst and NFP, with the two parties gaining 370 and 216 votes respectively — Rosarine Lagi getting 206 of the latter. Overall, the 2018 elections revealed a gradual fall in the former dominance of FijiFirst, with opposition parties greatly improving their standing in Rotuma (Figure 3). ${ }^{6}$ 


\section{Figure 3: Total votes won by major parties in 2014, 2018}

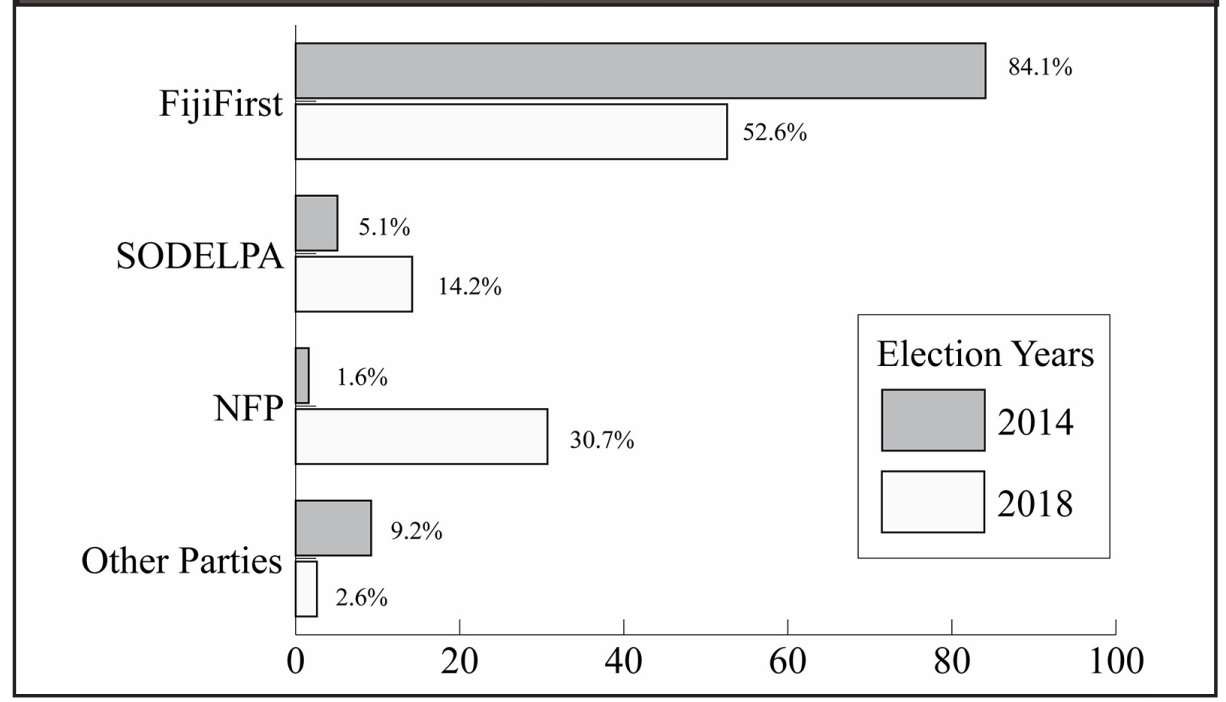

Note: Total votes (\%) garnered by the major political parties in the 2014 and 2018 national general elections on the island of Rotuma.

\section{Political Rotuman social media: Affordances for elections?}

Rotuma's geographic isolation and irregular government transportation services to Rotuma have meant that mass media such as newspapers are not readily accessible on the island. The geographic isolation has also meant that access to radio and television stations is difficult, and typically only possible for residents with access to satellite dishes. An example highlighting Rotuma's remoteness and the consequent difficulties in accessing mass media is an interview with a participant who recounted a story of her late husband and his prized transistor radio:

\footnotetext{
'Konousi (Pseudonym) had an old transistor [radio] that he looked after very well, in the evenings he would tune it to see if he can catch [a radio station signal]. Sometimes he would get the Tuvalu music [connect to Tuvaluan radio stations], very few times he would get Fiji [radio stations]'. (Interview in Rotuma, 2018)
}

In the present day, the majority of households interviewed in Rotuma now own a mobile phone. In many cases, houses would have owned both a Digicel network mobile phone, and a Telecom Fiji Limited 'Easy Tel' wireless phone. The 'Easy Tel' handset could be charged and taken around the island for calls, while the Digicel mobile phone could be used to call, text, and access the internet if one were in an area with Digicel network access.

The ability of Rotumans to use such telecommunications services has allowed them the affordance of having access to other Rotuman networks. In essence, before the advent of the internet and mobile telecommunications, Rotuman 
networks were typically limited to their family and community, as well as any updates brought in via arriving ships and planes. Mobile technology affords increased networking possibilities. This has led to Rotumans on Rotuma being able to become more closely connected with the Rotuman diaspora.

This affordance has expanded information horizons for Rotumans in Rotuma. Participants in Rotuma stated that with their smartphones, they could get exposure to a variety of news ranging from what was happening in sports, to how the government was behaving.

'It's very important I keep up to date. My kids in Fiji update me when we talk [on the phone] ... Sometimes it's just about who's getting married and all that. Other times, they update me on what's happening in the government, the [rugby] sevens.' (Vamarasi, 2018 [Pseudonym])

'Bainimarama came; I was one of those people who asked him whether it is possible to have Vodafone or Digicel.... If there was more connectivity on this side [of the island] I would use the internet more.... It's very good for me to know what's happening.' (Aliti, 2018 [Pseudonym]) (Interviews in Rotuma, 2018)

Rotumans of the diaspora have also been active in using the affordances of mobile technologies to keep their families in Rotuma informed. Their families in Rotuma have also used creative means to mitigate the issue of limited mobile phone connectivity; as Rosarina (pseudonym) stated in a 2018 focus group in Nadi;

'Mom and dad stay in Juju, so it's just on the edge of the Digicel [signal range]. So the phone doesn't catch [network] in the house. But there's a coconut tree at the back where it catches. So they put the phone in a bag and hang it there. We will text them and tell them when we will call. So they can see the text and be ready at the time when we will call.' (Interview in Western Division, Viti Levu (2018))

The flow of information is two streamed, with Rotumans on Rotuma providing updates to Rotumans on mainland Fiji. As focus group participants noted;

It [social media] keeps me in touch with family. Also, the updates, who's alive, who's dying. Like you get a shock, you find out this is happening, all on social media. [Interjection by another participant]; Yeah, you can see who is graduating, who is studying further and all that. (Focus Group, 2018)

In areas with strong connectivity to mobile and internet networks, or which are close to an area of strong internet connectivity, Rotumans used a mixture of SMS messaging and social media chats to stay connected and also reduce communications costs. As Rigamoto (pseudonym) stated in a focus group: 
'I text [SMS] my sister the time to be at the school ground [Malha'a High School]. Over there [school ground], the internet catches. So she tops up her data plan and will go to the ground. That way we can chat as long as we want on the data plan and it's cheaper than always texting [SMS].' (Interview in Rotuma, 2018)

Overall, the advent of mobile networks in Rotuma has resulted in a reduction in the cost of communications. This further facilitates the affordance of Rotumans broadening their networks, as the cost of communication becomes a less cumbersome burden. The Digicel network also offers promotional features such as free mobile internet data and talk time. This increases the ease by which Rotumans can communicate. As articulated by a Fiji based focus group participant (2018):

'I send mom and dad money. Before, it was really expensive to call, but now, they live in Itu'muta, which is so close to the tower. So they get their weekly plan, and its unlimited calls. So now we can always update each other.' (Isimeli, 2018 [Pseudonym]) (Interview in Western Division, Viti Levu, 2018)

Being politically integrated with Fiji has meant that vital administrative decisions relating to Rotuma are typically made outside of Rotuma, with Rotumans only knowing such matters when they have come to pass. Mobile technologies and social media offer the function of real-time news updates. This has allowed them the affordance of being able to have greater access to Rotuma related content based online.

A key example of this was the advent of the Rotuma bills. The function of connectivity offered by mobile technologies led to Facebook forums becoming a focal point for political discussions relating to the bills. Out of all the Rotuma related pages and groups, 'Rotumans on Facebook' is the largest. The group was initially created in the year 2008 by Betty and Sefeti Walker who are based in Australia. As of July 2020, the Facebook group 'Rotumans on Facebook' has amassed an impressive 13,000 members. Given that the total Rotuman population in Fiji as of the 2007 census is only 10,335 (and may be much higher today), this would constitute a substantial number of Rotumans within and without Rotuma.

When the Rotuma bills were tabled, Rotumans employed social media to immediately disseminate copies of the bills and carry out discussions on the merits and demerits of the bills. In this case, the mass communications function of social media afforded Rotumans an opportunity to easily share and access Rotuma related content.

Focus group and interview participants alluded to how social media had allowed for the Rotumans to disseminate information relating to the bills. The mass communications feature of social media also afforded Rotumans the opportunity to organise their protests over the bills;

234 PACIFIC JOURNALISM REVIEW 26 (2) 2020 
'When the bills came out, I found out through my friends [on Facebook]. I'm cousins with .... [Rotuman Lawyer] so they were asking if I can see if she knows anything about them.' (Jiare, 2018 [Pseudonym])

'I was checking the group every day [Rotumans on Facebook]. I don't know about the law but good thing we have educated people [referring to Rotumans of the diaspora] there what can tell us what it all means.' (Marseu, 2018 [Pseudonym]) (Interviews in Rotuma, 2018)

Other interview participants were also individuals who had taken an active role in being the disseminators of information on Facebook. One interviewee spoke on how he had used Facebook to make sure all is kaianaga (relative) were kept informed:

'I'm an IT person. So I use the technology to help my people. I would post all the time when there's updates from Rosie [Rosie Lagi, the Rotuman lawyer who ran for elections in 2018] ... I also make sure I message and call my family at home [Rotuma].' (Munivai, 2018 , [Pseudonym]). (Interview in Western Division, Viti Levu, (2018)

Social media and the internet have the propensity to act as public spheres. In the case of Rotuma, the research observes that social media has helped facilitate both a virtual and physical public sphere.

Through the course of the research (and from previous visits by the researchers to Rotuma), multiple instances were noted of Rotumans gathering in areas with stable network connections to check social media. During such impromptu gatherings, conversations amongst those physically present tended to revolve around sharing what they had viewed or learnt online. Conversations ranged from the photos from a recent wedding, to updates on the Rotumans on a Facebook page pertaining to shipping issues.

\section{Digital elections education: Mobile technologies affording elections awareness}

As mentioned, the electoral provisions of the 2013 constitution pose a challenge for minority groups who may wish to for representation in parliament. Anderson (2007) notes that political discourse in Fiji tends to focus upon 'major players', and that Party manifestos tend to focus on majority communities. Anderson (2007, p. 185) further notes that media attention focusses upon issues affecting dominant communities 'centralised around the capital, or at least the main islands of Viti Levu and Vanua Levu' (p. 185). In this context, Rotuma specific issues are often drowned out in both political discourses, and the mainstream media. This trend seemed to continue during the 2018 elections buildup, with much of the political campaigning, and media discourse tending to neglect Rotuma. A telling example of this is the fact that of the six parties that contested Fijis 2018 elections, only two parties (NFP and Fiji First) made any 
reference to Rotuma in their manifestos. Furthermore, of the 235 candidates in the 2018 elections, only one candidate (Rosarine Lagi) ran on a platform that specifically targeted the Rotuman issues and the Rotuman electorate.

Rotuman issues have thus been subsumed within the broader spectrum of national-level political discourse. Additionally, with a lack of coverage of Rotuman issues during elections, Rotumans on Rotuma do suffer from an inadequacy of information. Individuals interviewed felt that this lack of access to information was a key issue Rotumans faced. This is encapsulated by a focus group participant who when asked what she felt was a current problem faced by Rotumans noted:

\begin{abstract}
... 'I mean not being informed about what's happening. Like not enough information ... people don't have enough media, or enough people updating them. Now we depend on Rosie [Lagi] when she goes. The other part is social [media]. [Interviewer]: So would you typically look to Facebook for these updates, like from Rosie? Like for updates regarding news from Rotuma and political [News]. Participant: Yes, and then I think of Rotuma you know, those that don't have access to Facebook. (Focus Group Participant, 2018)
\end{abstract}

Interviewees and focus group participants also acknowledged the fact that Rotuma was on the wrong side of the digital divide. However, many did feel that social media did have a role in informing Rotumans on Rotuma. Whereby social media platforms can provide a means for Rotumans to educate each other on general, and election-related issues. The information-sharing function of social media can potentially alleviate the issue of a lack of election-related information that Rotumans face. As a focus group participant noted;

\footnotetext{
'It can [help] with the young ones on it [Facebook]. Because the young ones are you know, more into it ... So they would be the ones who we be oh ok, this is this, you know. Telling their elders... But I think if there was a better connection it would be open to more Rotumans.' (Fatiaki, 2018 [Pseudonym]
}

Rotuman youth have also stated that they would like to vote for individuals who could provide a focus on Rotuma. As Taito (pseudonym), a Viti Levu based focus group participant noted: 'Mainly, we are voting for the people, or the party, that can do more for the island [Rotuma]' (Focus Group, 2018).

Facebook offers the functionality of open and real-time discourse among Facebook users. This can provide the affordance of open and transparent debate among Rotumans. Despite this, there is at times an age dynamic that materialises during social media discussions among Rotumans. A youth focus group participant noted that while they would follow the discussions on the Rotumans on Facebook page, they would not themselves comment and post, as they felt 
it opened themselves up to criticism from 'the elders'.

During the build-up to Fiji's 2018 elections, Rotuma focused groups on social media were used to disseminate information related to elections. Some posts promoted and endorsed a Rotuman candidate. As aforementioned, NFP candidate Rosarine Lagi played a key role in raising awareness on the negative ramifications of the Rotuma bills. There were numerous posts in Rotuma specific Facebook groups that called on Rotumans to vote for her based on her leading role in opposing the bills (Figure 4). In addition, Rotumans on Rotuma used social media to provide updates of electoral preparations on the island of Rotuma.

Being Rotumans themselves, and being part of the Rotuman online community, the researchers noted numerous instances of Rotumans employing social media to provide election-related updates. In the build-up to Fiji's November 2018 elections, Facebook groups such as Rotumans on Facebook, and Rotumans for Rotuma became hotbeds for political discourse. Online conversations ranged from the promotion of various parties and candidates to means by which Rotuma specific issues could be raised at the parliamentary level.

\section{Conclusion}

Social media offers a vast array of functions and affordances for Rotumans. With the majority of Rotumans residing outside of Rotuma, Rotumans have harnessed social media to maintain connections with the diaspora. Through social media, Rotumans can harness familial and community networks to stay informed on Rotuma related issues. Being a minority ethnic Indigenous group, social media offer a potential avenue for Rotumans to raise issues that impact them. With the changes to Fijis electoral system having profound ramifications for Rotuman political representation, social media also offers a means for Rotumans to communicate and disseminate political information. With social media facilitating improved connectivity between Rotumans, it has offered the affordance of expanded networks.
It is official today Rosie Lagi is now a on November 14th 2018. Rotumans will remember Rosie Lagi for her work on the Rotuma Bills that are still before the Fiji parliament. We still have a lot of work to do on the Rotuma Bills and it is important we have a important to Rotumans as a unique group of people, their culture, tradition and the protection of their inherited land and sea

Having stood before the Standing Committee in November 2016 assigned to report to the Fiji Parliament on the Rotuma bills Petition alongside Rosie Lagi I would strongly recommend your support for Rosie Lagi. The
Rotuma Bills remain in the Fiji Parliament and there is no guarantee the voice of Rotumans will be heard if the bills are passed as law

Alalum 'ou garue se famor Rotuma ma 'otmota Rotuma.

Figure 4: Facebook post in support of a Rotuman political candidate on 8 October 2018. 
However, while social media has offered increased visibility, and ease of communication, the digital divide between Rotumans within and without Rotuma has hindered the efficacy of social media affordances. While Rotumans on Rotuma can employ social media to increase visibility for the issues they face, this is often dependent upon the efficacy of the mobile networks. Despite these hindrances, Rotumans have acted creatively to try and gain maximum benefit from the functions of mobile communication and social media. Those who have access to mobile and internet networks on Rotuma act as a conduit of data for those without mobile network access. In this sense, Rotuman usage of social media can be seen to characterise a contemporary 'coconut wireless'.

\section{Notes}

1. Data from the Fiji 2007 census is used rather than the 2017 census data, due to the 2007 census being the last time where ethnicity specific data was collected. 2. Seats in the lower house were communally allocated, maintaining parity among Indigenous and Indo-Fijians with 22 seats each and 8 seats for General Electors. Of the 52 seats, 27 were communal reserved seats $(12$ each for Indigenous Fijian and Indo-Fijians and 3 for General Electors) while 25 seats were national seats, to be elected cross-nationally (10 seats each for Indigenous Fijians and Indo-Fijians and 5 for General electors) (Fiji Government 1970). The introduction of national, crossvoting seats was an attempted compromise between the Indigenous Fijian desires for communal representation based on communal rolls and the Indo-Fijian commitment to a 'common roll' (Ghai \& Cottrell, 2008, p. 292).

3. The Council of Rotuma consists of all district chiefs and their appointed subchief to the council, including the Chief Medical Officer, and the District Officer on the Island. 4. Any amendments to the two Acts relating to Rotuma could not be made without the supporting votes of 6 out of the 8 members of the Senate nominated by the Council of Chiefs.

5. Rosarine Lagi is the same individual who ran in the 2014 elections as a Fiji Labour Party candidate.

6. Due to the lack of exit polling in Fiji, it is exceedingly difficult to assess how Rotumans on mainland Fiji voted.

\section{References}

Anderson, K. J. (2007). From marginalization to mainstream? Rotuma and the 2006 election. In J. Fraenkel \& S. Firth (Eds.), From election to coup in Fiji (pp. 185-203): Canberra, ACT: Australian National University (ANU) Press.

Biggs, B. (1965). Direct and indirect inheritance in Rotuman. Lingua, 14, 383-415.

Bolatiki, M. (2018, 20 April). MV Brianna to take rations to Rotuma. Fiji Sun. Retrieved from https://fijisun.com.fj/2018/04/20/mv-brianna-to-take-rations-to-rotuma/

Chand, P. (2017, July 30). Implications of the draft Rotuma bills: A question of identity. Islands Business.

Clark, C. (2005). The Rotuma website: Transnational relations and the articulation of 
cultural identity. Unpublished MA thesis, the University of British Columbia, Canada.

Coka, A. (2014a, May 22). \$15 million upgrade for Rotuma airport. FBC News. Retrieved from https:/www.fbcnews.com.fj/news/15-million-upgrade-for-rotuma-airport/

Coka, A. (2014b, May 21). Developments on Rotuma widely welcomed. FBC News. Retrieved from https://www.fbcnews.com.fj/news/developments-on-rotuma-widelywelcomed/

Coka, A. (2014c, May 27). PM directs WAF to waive bills in Rotuma. FBC News. Retrieved from https:/www.fbcnews.com.fj/news/pm-directs-waf-to-waive-billsin-rotuma/

Coka, A. (2014d, June 8). Rotuma to improve trade with Tuvalu. FBC News. Retrieved from https://www.fbcnews.com.fj/news/rotuma-to-improve-trade-with-tuvalu/

Evans, S. K., Pearce, K. E., Vitak, J., \& Treem, J. W. (2016). Explicating affordances: A conceptual framework for understanding affordances in communication research. Journal of Computer-Mediated Communication, 22(1), 35-52.

Fiji Bureau of Statistics. (2007). Rotuma Census of Population. Retrieved from http:// www.statsfiji.gov.fj/index.php/component/content/article/9-social-statistics/socialgeneral/113-population-and-demography21

Fiji Bureau of Statistics. (2018). 2017 Population and Housing Census Release 1: Age, Sex, Geography and Economic Activity. Suva, Fiji: Fiji Bureau of Statistics.

FijiFirst Party. (2018). FijiFirst manifesto 2018. Fiji: FijiFirst Party.

Fiji Sun. (2014, July 13). Government talks Rotuma-Tuvalu trade. Retrieved from https:// fijisun.com.fj/2014/07/13/government-talks-rotuma-tuvalu-trade/

Fiji Sun. (2018, October 30). \$12.8 million runway for Rotuma opened. Retrieved from https://fijisun.com.fj/2018/10/30/12-8-million-runway-for-rotuma-opened/

Fiji Village. (2014, January 24). \$10m renewable energy project to be launched soon. Retrieved from https:/fijivillage.com/news/10M-renewable-energy-project-to-belaunched-soon-2k9rs5/

Fiji Village. (2018). Fiji general elections 2018 Results. Retrieved from http://fijivillage. com/election-2018-results/

Flanders Marine Institute. (2018). The intersect of the Exclusive Economic Zones and IHO sea areas. Retrieved from http:/www.marineregions.org/

Genzuk, M. (2003). A synthesis of ethnographic research. Occasional Papers Series. Center for Multilingual, Multicultural Research (Eds.). Center for Multilingual, Multicultural Research, Rossier School of Education, University of Southern California. Los Angeles, 1-10.

Ghai, Y., \& Cottrell, J. (2008). A tale of three constitutions: Ethnicity and politics in Fiji. In S. Choudhry (Ed.), Constitutional design for divided societies: Integration or accommodation? (pp. 287-315). Oxford, UK: Oxford University Press.

Ginsburg, F. (1997). From little things, big things grow: Indigenous media and cultural activism. In D. Fox \& O. Starn (Eds.), Between resistance and revolution: Cultural politics and social protest between resistance and revolution (pp. 118-144). New Brunswick, NB: Rutgers University Press.

Ginsburg, F. (2008). Rethinking the digital age. In P. W. M. Stewart (Ed.), Global indigenous media: Cultures, poetics, and politics. (pp. 287). Durham, NC: Duke University Press.

Howard, A. (1970). Learning to be Rotuman: Enculturation in the South Pacific. New York, NY: Teachers College Press.

Howard, A., \& Rensel, J. (2007). Island legacy: A history of the Rotuman people. Oxford, UK: Trafford Publishing. 
Inia, E. K. M. (1998). Fäeag 'Es Fuaga: Rotuman Proverbs. Suva, Fiji: Institute of Pacific Studies, The University of the South Pacific.

Irava, I. (1991). The emigration of Rotumans to Fiji. In C. Plant (Ed.), Rotuma (pp. 153160). Suva, Fiji: Institute of Pacific Students, The University of the South Pacific.

Kant, R. (2017). Casting a blind-eye: Is Fiji's 2013 'ethnically-blind' constitution a path to democratic stability? Journal of South Pacific Law, 2017, 3-36.

Kant, R. (2018). Constitutional re-design for democratic stability in a divided society: A Fiji case study. Unpublished Master of Arts thesis, The University of the South Pacific, Suva.

Kant, R., \& Rakuita, E. (2014). Public participation \& constitution-making in Fiji: A critique of the 2012 constitution-making process. Ssgm Discussion Paper, 2014 (6).

Khalidi, R. (1997). Palestinian identity: The construction of modern national consciousness. New York, NY: Columbia University Press.

Kozinets, R. V. (2010). Netnography: Doing ethnographic research online. London, UK: Sage Publications.

Moser, R. G. (2008). Electoral systems and the representation of ethnic minorities: Evidence from Russia. Comparative Politics, 40(3), 273-292. doi:10.2307/20434082

Mpofu, S. (2013). Social media and the politics of ethnicity in Zimbabwe. Ecquid Novi: African Journalism Studies, 34(1), 115-122.

Nasiko, R. (2015, April 25). Roadworks on island. The Fiji Times. Retrieved from https:// www.dd.mobile.fijitimes.com.fj/roadworks-on-island/

National Federation Party. (2018). Manifesto of the National Federation Party: 2018 general elections. Suva, Fiji: National Federation Party.

QGIS Development Team. (2019). QGIS Geographic Information System. Retrieved from http://qgis.osgeo.org

Rotuma Act 1958 (Cap. 122) (Rotuma Act)

Sackett, L.-A., Kant, R., \& Titifanue, J. (2018). The Rotuma bill no. 6 of 2015: What is at stake for Rotuma? SGDIA Working Paper Series, 4. Retrieved from https://www. usp.ac.fj/fileadmin/files/faculties/business/SGDIA/SGDIA_Working_Paper_Series_-_No.4___Final.pdf

Sreberny-Mohammadi, A., \& Mohammadi, A. (1994). Small media, big revolution: Communication, culture and the Iranian revolution (NED - New edition ed.). Minneapolis, MN: University of Minnesota Press.

The Fiji Times. (2014, February 1). Dredging to improve services. Retrieved from https:// www.fijitimes.com.fj/dredging-to-improve-services/

The Fiji Times. (2017, January 20). Bills Rebuff. Retrieved from https://www.fijitimes. com/bills-rebuff/

The Fiji Government. (2014a, May 15). New hospital for Rotuma. The Fijian Government Media Release. Retrieved from https://www.fiji.gov.fj/Media-Centre/News/ NEW-HOSPITAL-FOR-ROTUMA?rss=news

The Fiji Government. (2014b, May 16). Road works to begin around Rotuma. The Fijian Government Media Release. Retrieved from https:/www.fiji.gov.fj/Media-Centre/ News/ROAD-WORKS-TO-BEGIN-AROUND-ROTUMA

Titifanue, J., Varea, R. R., Varea, R., Kant, R., \& Finau, G. (2018). Digital diaspora, reinvigorating indigenous identity and online activism: Social media and the reorientation of Rotuman identity. Media International Australia, 169(1), 32-42. doi:https:// doi.org/10.1177/1329878x18803377

Valenzuela, S., Arriagada, A., \& Scherman, A. (2014). Facebook, Twitter, and youth engagement: A quasi-experimental study of social media use and protest behavior using 
propensity score matching. International Journal of Communication, 8, 2046-2070. Vasil, R. K. (1972). Communalism and constitution-making in Fiji. Pacific Affairs, $45(1), 21-41$.

The authors would like to express their special thanks to Professor Heather Horst (Western Sydney University), and Professor Robert Foster (University of Rochester) for the acquisition of funding and oversight for this project (Grant Number: DP140103773).

Rufino Varea is a PhD candidate at the School of Marine Studies, The University of the South Pacific, Suva, Fiji.

Jason Titifanue is an assistant lecturer at the School of Government, Development and International Affairs, The University of the South Pacific, Suva, Fiji; a Development Leadership Programme (DLP) research associate; and an Honorary Research Associate at the Institute of Human Security and Social Change (IHSSC), La Trobe University, Melbourne, Australia.

wesleytitifanue@gmail.com

Renata Varea is a research associate at the School of Geography, Earth Science and Environment, The University of the South Pacific, Suva, Fiji.

Romitesh Kant is a Development Leadership Programme $(D L P)$ research associate; and an honorary research associate at the Institute of Human Security and Social Change (IHSSC), La Trobe University, Melbourne, Australia. 